\author{
ANNA HEDO, \\ Borys Grinchenko Kyiv University (Kyiv, Ukraine) \\ e-mail: a.hedo@kubg.edu.ua, ORCID 0000-0003-4151-0747 \\ OLGA SARAJEVA, \\ Priazovskyi State Technical University (Mariupol, Ukraine) \\ e-mail: saraeva.ov84@gmail.com, ORCID 0000-0001-5305-6751
}

\title{
CHARTERS AND UNIVERSALS OF UKRAINIAN METROPOLITANS AND ARCHBISHOPS GIVEN TO THE NIZHYN GREEK COMMUNITY: SOURCE-STUDY DISCOURSE
}

\begin{abstract}
The article analyzes the charters of the Kyiv metropolitans, archbishops of Kyiv and Chernihiv as act materials on the history of the Greeks of Ukraine in the second half of the 17th - 18th centuries. On the basis of source study and comparative-typological analysis, their evolution and significance for the church structure of the Nizhyn Greek Brotherhood, which was under the authority of the Metropolitan of Kyiv and the Archbishop of Chernihiv up to the end of the 17 century, and from the beginning of the 18 century it was subordinate only to the Kyiv metropolitanate, is considered. From the very beginning of the Greek settlement in Nizhyn, the church authorities looked positively on their needs and provided them with all possible assistance. Evidence of this were the numerous charters, universals, orders, "oprichna letters" of the Kyiv metropolitans, archbishops of Kyiv and Chernihiv, orders of the Kyiv Orthodox Consistory Church. Most of them were published in the collection of acts by Professor A.A. Fedotov-Chekhovsky, which was published from the archives of St. Michael's Church in Nizhyn. The collection contains Greek and Slavic texts of 24 charters of Orthodox Greek and Ukrainian hierarchs of 1680-1784, which gave the Greeks the right to establish their own church brotherhood or confirmed such a right. Textological and source analysis of A.A. Fedotov-Chekhovsky's publication and five universals given to the Nizhyn Greeks by L. Baranovich, published by an unknown author in 1865 in the "Chernihiv Eparchial News", and M. Storozhevsky's materials has revealed textual and chronological differences.
\end{abstract}

Key word: Source; Charters; universals; orders; oprichna letters of Kyiv metropolitan and Chernigiv Archbishops; Nizhyn Greek Community.

\section{Introduction}

In the second half of the 17th century, Greek merchants appeared in the Ukrainian state. They chose Nizhyn as their place of residence and it was not a random choice. Nizhyn was one of the largest cities in Ukraine and due to its good geographical location played the role of a large and important trade center. In the 17th18th centuries, overland trade routes connecting Moscow, Siberia and the Volga region with the trading cities of Ukraine, Lithuania, Poland, Germany, Crimea and further leading to Europe, the Balkan Peninsula, the Mediterranean and the Middle East crossed here. Another reason for the settlement of Greeks in Ukraine was caused by the dramatic circumstances of the loss of national and state independence by the Greek people. After the fall of Constantinople in 1453, there were difficult times of Ottoman occupation for the Orthodox people of Greece. To save the national culture, native language and Orthodox faith, thousands of Greeks emigrated to neighboring lands. Moving to the countries of Eastern Europe in compact groups, they built churches and monasteries there, and opened schools, libraries, and established Orthodox brotherhoods here.

The Greek colony was originally formed as a religious brotherhood and was a unique phenomenon in the history of Ukraine. It is clear why the Greeks chose such a form of social organization: brotherhoods were widespread organizations in Ukraine in 16th-17th centuries. Although the Greek colony in Nizhyn was formed in the 1780s around the Church of the Holy Archangels Michael and Gabriel, only on July 3 1696, the Metropolitan of Kyiv and Galicia signed a charter giving the Greek community legal status, i.e. the right to live in a church brotherhood, elect a presbyter, establish a school and hospital. Since then, the Greeks appealed to senior officials and church hierarchs on behalf of the brotherhood and for its prosperity.

From the very beginning of the Greeks' settlement in Nizhyn, the church authorities, as well as the Hetman government had a positive attitude to their needs and interests and, for their part, provided all possible assistance. Evidences of this are the numerous blessing charters and universals of the Kyiv metropolitans, archbishops 
of Kyiv and Chernihiv granted to the Nizhyn Greek community in the late 17 th -18 th centuries.

The purpose of research is a comprehensive sourcestudy analysis of charters and universals of senior clergymen of Ukraine provided to the Nizhyn Greeks and the identification of their information capabilities.

\section{Research methods}

The methodological basis of the study is the use of the source study method as a system of research procedures, the elements of which are: source characteristics; clarification of the circumstances under which the source was created, identification of a set of problems related to its functioning in the reality of that time; interpretation of the content of the source and assessment of its informative capabilities. The classification method made it possible to identify the peculiarities of the internal structure of the act sources of representatives of the highest spiritual authority, to establish links between different types of documents. The hermeneutic method was used to analyze the text of the sources, the necessity of which was connected with the use of specific terminology of the 17th-18th centuries, obsolete and foreign words and phrases in the recordkeeping.

More than two hundred years of existence of the Greek community in Nizhyn has attracted and continues to attract the attention of many researchers. Researcher of its history K. Charlampowycz defined its place in history as follows: "The Greek colony in Nizhyn is a remarkable phenomenon in the history not only of Ukraine, but also of the whole former Russian Empire" (Charlampowycz, 1924: 1). Its coverage was directly or indirectly touched upon in the researches by prominent historians of the 19th and early 20th centuries and contemporary researchers.

The church history of the Greek community in Nizhyn has a significant historiography. Its coverage was directly or indirectly touched upon in studies by such prominent historians of the 19th - early 20th centuries as O. Dmitrievsky, M. Plokhynsky, K. Charlampowycz and contemporary researchers $\mathrm{E}$. Chernukhin, O. Morozov.

The work of M.K. Storozhevsky (1863) tells the history of the Nizhyn Greek community from B. Khmelnytsky's hetmanship and the creation of the church brotherhood to the middle of the 19th century. The author analyzed the hetman's universals and charters of representatives of Ukrainian highest spiritual authorities, which regulated the public and ecclesiastical life of the Nizhyn Greeks.

Well-known expert of liturgical literature A. Dmitrievsky covered the history of the Nizhyn Greeks through the history of churches and parables. In April 1884, he visited Nizhyn and became interested in the books and manuscripts kept in the bell-tower of the Church of the Holy Archangels Michael and Gabriel, where he got to clarify some liturgical issues thanks to friendly relations with the former churchwarden of the Greek churches Anastasia Kunelaki and the priest Iliodorus. The author calls Father Christopher Dmitriev the founder of the brotherhood, ktetor of both churches and the author of the Statute of the Nizhyn Greek Brotherhood. Reporting many interesting facts from the history of the foundation and construction of churches, the researcher cites documents to confirm the facts (Dmitrievsky, 1885).
In his speeches on January 18 and 221890 at the VIII Archaeological Congress in Moscow, A. Dmitrievsky spoke in detail about the history of the brotherhood. The researcher emphasized that Metropolitans Lazar Baranovich and Varlaam Yasynsky, as well as Hetman I. Mazepa were persons who contributed to the spiritual formation of the brotherhood (Trudy VIII Arheologicheskogo sjezda.., 1897: 114).

The largest volume of material on the history of the Nizhyn Greeks among all publications during the Russian Empire is contained in the work by M.M. Plokhinsky "Foreigners in Old Malorossiya" (1905). The author narrates the charters of metropolitans' and hetmans' universals according to the publication of A. Fedotov-Chekhovsky. Coverage of the the Nizhyn Greeks' church history is mainly based on the research of A. Dmitrievsky. The researcher also touches upon the issue of the stay of famous Greek clergy representatives in Nizhyn.

A significant contribution to the study of the historiographical and source-study tradition of the Nizhyn Greek community was made by $\mathrm{E}$. Chernukhin in his work "The Nezhin Greek Brotherhood: Historiography and Sources" (1998). This is the only work at this time that covers historiography and analyzes the existing archive of the Nizhyn Greek community. The author researched a number of unpublished and little-known works of domestic and foreign scholars and touched upon the preservation of the archival heritage of the Nizhyn Greeks.

Protoiereus O. Morozov devoted his research to the history of Greek churches. On the basis of the materials of the Institute of Manuscripts of the Central Scientific Library of the National Academy of Sciences of Ukraine named after V. Vernadsky, Nizhyn branch of the State Archives of Chernihiv region and literature, he recreated the process of building Greek churches in Nizhyn (Morozov, 2013).

Comprehensive analysis of act materials of the middle of the 17th - 19th centuries covering the history of the Greek communities in Nizhyn and the Northern Priazovye from the founding to the repeal of facilities and privileges is considered in the monograph by A. Hedo (2005).

However, despite the large number of studies that directly or indirectly address this issue and contain rich factual material on the church history of the Nizhyn Greek Brotherhood, a comparison of their information with documentary sources shows that in some cases they made mistakes.

\section{Results and discussion}

From the very beginning of the settlement of the Greeks in Nizhyn, the church authorities, as well as the Hetman government had a positive attitude to their needs and interests and, for their part, provided all possible assistance. Evidence of this are the numerous blessing charters, universals, orders, oprichna letters of the Kyiv metropolitans, archbishops of Kyiv and Chernihiv, orders of the Kyiv Orthodox Consistory Church.

Charters, universals, orders, oprichna letters of Greek hierarchs and Kyiv metropolitans, orders of the Kyiv Orthodox Consistory Church given to Nizhyn Greeks were published in the collection of acts by Professor A. Fedotov-Chekhovsky, which was published from the archives of St. Michael's Church in Nizhyn. The first section of the collection contains Greek and Slavic texts of 24 charters of Greek and Ukrainian Orthodox hierarchs, which gave the Greeks the right to establish their own 
church brotherhood or affirmed this right. The researcher presented documents of the highest spiritual authority charters, letters, decrees, certificates, affirmative patents for 1680-1784.

However, as O. Dmitrievsky rightly noted, the absence of any preface in A.A. Fedotov-Chekhovsky's publication deprived the reader of information about the place of storage of published documents. The publisher also did not mention that some of the act materials cited by him had already been published. These are five universals given to the Nizhyn Greeks by L. Baranovich, published by an unknown author in 1865 in the "Chernihiv Eparchial News" (Pysma Preosvyashhennago..., 1865: 311-317). Comparison of the latter with the publication by A.A. Fedotov-Chekhovsky leads to the discovery of not only textual, but, first of all, chronological differences: Lazar Baranovich's universal on ordering the ktetors of the Greek Church of St. Michael the Archangel to transfer all church property to Father Christopher was dated November 271682 in "Chernihiv Eparchial News" and November 71689 by A.A. Fedotov-Chekhovsky.

A comparison of M. Storozhevsky's materials with the collection by A.A. Fedotov-Chekhovsky leads to the following conclusions: The Blessed Charter of Administrator of the Kyiv metropolitanate, Bishop Kirill Shumlyansky, dated July 18,1719 by Fedotov-Chekhovsky, is dated 1710 by M. Storozhevsky, the Blessed Charter of Kyiv Metropolitan Arseniy Mohylyansky dated June 281762 is absent in materials by M. Storozhevsky (FedotovChekhovsky, 1884c: 20). As O. Dmitrievsky noted, A.A. Fedotov-Chekhovsky ignored the charter of Victor, Archbishop of Chernihiv, dated December 22 1796, as well as the decree signed by the Chernihiv bishops, dated April 21786 (Dmitrievsky, 1885: 379).

The charters of church hierarchs are an important type of sources of act character in the study of the legal system and church traditions of the Nizhyn Crusade Brotherhood. The following parts can be distinguished in them: 1) name, surname and rank of the clergyman; 2) appeal to the persons to whom the charter was addressed; 3 ) a description of the events that caused the issuance of the act; 4) resolution of the case; 5) date; 6 ) signature of the clergyman; 7) seal. These main sections go through all the charters of the metropolitans, but in different forms.

The name and surname of the clergy are found in one form: Jacob, Lazar Baranovich, Gedeon Svyatopolk, Varlaam Yasynsky, Varlaam Vanatovych, Rafail Zaborovsky etc. In addition, the act materials of the clergy necessarily indicated the rank: Jacob - "Archbishop of Constantinople, New Rome, and Ecumenical Patriarch", Lazar Baranovich - "Archbishop of Chernihiv, Novgorod and all North", Gedeon Svyatopolk - "Orthodox Archbishop, Metropolian of Kyiv, Galicia and all Russia, Bishop of Lutsk and Ostroh", Varlaam Yasynsky, Varlaam Vanatovych, Rafail Zaborovsky, Tymofiy Shcherbytsky, Arseniy Mohylyansky had the same title "Orthodox Archbishop, Metropolitan of Kyiv, Galicia and all Little Russia".

Appeals were also transmitted in different ways: "to all pious citizens of the Nizhyn spiritual and secular people", "all people of spiritual and secular status in need to know", "all the inhabitants of the city of Nizhyn, and especially the Greeks", "to everyone in vow and especially to everyone to whom this Our writing will be shown", "to all the predestined and common people of spiritual and secular state of who want to know", "let us acquaint all who need to know that", "all the pious of Our humility and obedient in the Holy Spirit", "to all who receive, honor and hear this writing".

The events in most acts of the highest spiritual authority of Ukraine are described without introduction. In some letters there is no description of events, and only the decision on the case is given. It is formulated mostly by the same phrases: "Let us acquaint our Archiereus blessing", "God's and our Archiereus blessing", "thus issued a decree Our Pastoral to the changed brotherhood of the Greeks", "blessing with the power given to us by God and allowing", "by this Archiereus scripture we declare".

The date mainly begins with the words "written", "given". The place of writing is marked: "in Chernihiv", "in Kyiv", and most often "in the cathedral of our Sophia of the Metropolitan of Kyiv". In the letters of the clergy on the left side there was a seal and the handwritten signature of the metropolitan with the words "by his own hand".

It should be noted that the act documents of clergy corresponded to the form of the acts of that time as act materials in the first part - the initial protocol. However, their main content was characterized by freedom of form, it was more concerned about the substance of the case than about compliance with protocol rules.

The first documents on this issue date back to 1680 . These are two charters of the Archbishop of Chernihiv, Novgorod and all North and the guardian of the Kyiv metropolitanate Lazar Baranovich and two charters of the Patriarch of Constantinople Jacob. It was at this time that an organization in the form of a church parish was formed in Nizhyn. The initiator of its creation was Christopher Dmitriev (Christodoulos), a priest from Northern Greece. Having settled in Nizhyn in 1677, he first entered the parish of St. Nicholas Cathedral, which at that time was visited by Nizhyn Greeks. However, due to a misunderstanding with the local priests, Father Christodoulos began to apply for the construction of a Greek church and the separation of the Greeks into a separate parish (Morozov, 2013: 28). It was the merit of Father Christodoulos that the "crusader" brotherhood was founded in Nizhyn, the Greek Orthodox parish was founded and the first Greek churches were constructed.

Thus, in 1679, the Greeks appealed to the Patriarch of Constantinople to allow them to build their church in Nizhyn. It should be noted that both letters of Patriarch Jacob are dated only from 1680 without the month and number. He was the first to take the church built by the Greeks in Nizhyn under his care and to bless the office of the spiritual father Christodoulos in this church: "so that the named church of the great highest-ranking official, located in the Nizhyn, was and remains all-free for all eternity, not subject to, not enslaved, completely unaffected by offenses and undisturbed from any person; so that do not be subordinated to none of all those who have power, to their influence and do not priest Father Christopher himself be disturbed, do not income is taken from him..." (Fedotov-Chekhovsky, 1884j: 4) In his letter, the metropolitan noted that all property and profits should belong to the church.

The letters issued in defense of the Greek clergy by Lazar Baranovich, Archbishop of Chernihiv, Novgorod and all North were of great importance to the Greeks. The first of them was issued on March 11 1680, in which he tried to protect the interests of local priests, who relied on parishes in the churches. But he failed to do so, because Greek merchants received people from other parishes in 
their churches and made a profit from it (FedotovChekhovsky, 1884j: 6).

Another charter of Lazar Baranovich is dated September 181680 and testifies that in seven months, the Greek church was built and named after the archangels Michael and Gabriel. The Greeks were allowed to have their priest in this church and to "officiate in the Greek language and to take confession of the Greeks who were there, wishing to open their consciences" (FedotovChekhovsky, 1884j: 7).

The Metropolitan's letter also stated that at this time the new church in Nizhyn was visited by Sophronius, Metropolitan of the Philippines, who gave a positive response to the work of the priest Christodoulos, describing it from the best side (Fedotov-Chekhovsky, 1884j: 7).

Three years later, on March 5 1683, Lazar Baranovich issued a blessed charter addressed to "all the inhabitants of Nizhyn, and especially to citizens of Greek descent", conditioning the rights of the Greek ecclesiastical brotherhood to freely choose its ktetors (church founders auth.) who had to keep the order in the church and provide it with everything necessary. The Greeks also received the right to elect a priest and keep him at their own expense. The charter established the amount of salary to be received by Christodoulos, who served at the Church of St. Michael the Archangel and was to receive one gold piece from the Greek community each day, as well as income from various rites (Fedotov-Chekhovsky, 1884p: 11-12). In addition, members of the brotherhood were allowed to build a Greek school and hospital at the church.

Although the Greek community of Nizhyn acquired the form of a "church brotherhood" thanks to the charters of the metropolitans, it was not a parish in the territorial sense, because it included not only settled Greeks, but also visitants. On the other hand, it was not a merchant community, rights of which were noted by Ukrainian hetmans (Charlampowycz, 1924: 17).

On May 10 1684, Lazar Baranovich issued an oprichna letter, reaffirming all the rights of the brotherhood and allowing two envoys of the Greek priest Christodoulos to raise funds for the construction of the church and payment of debts for the decoration of the Church of St. Michael the Archangel "of the Greeks ... a lot of people live in Nizhyn" (Fedotov-Chekhovsky, 1884l, 12-13).

Although the rights of Christodoulos in the Greek parish were protected by three charters of Lazar Baranovich, two charters of Patriarch John and a universal of $I$. Samoylovych, he sought new evidence of his independence from the Kyiv Metropolitan Gedeon Svyatopolk. In the last letter dated May 1 1686, he expressed the wish that Christodoulos "... should not have any obstacles from anyone; so that he could calmly pray for the strong power of Their Royal Highness, for the victory over the enemies, and for the conciliation of the whole world remaining in the temple of the high-ranking Bishop of Heaven" (Fedotov-Chekhovsky, 1884k: 14).

In 1696, Metropolitan of Kyiv Varlaam Yasynsky was appealed by "pious people, foreign Greek merchants, wandering in Little Russia, and living in the God-saved city of Nizhyn having here their own Greek church, the first church of the Cathedral of the Holy Archangel Michael is wooden, also the Church of All Saints is made of stone" (Fedotov-Chekhovsky, 1884c: 17-22) with a request to confirm the decision to form a Greek church brotherhood and allow them: "to have a spiritual fraternal union of the church brotherhood at their Greek Nizhyn church, belonging to a pure attendance and obedience to no one but to the Orthodox throne of Our Saint Sophia Metropolitan of Kyiv" (Fedotov-Chekhovsky, 1884c: 17).

On July 3 1696, Varlaam Yasynsky confirmed the existence of the brotherhood with a blessed charter. According to this document, the Greeks had to depend in spiritual matters only on the Metropolitan of Kyiv (FedotovChekhovsky, 1884c: 17). The brotherhood was given the opportunity to elect a priest, whose candidacy had to be approved by the metropolitan. In this choice, the brotherhood had to take into account that the priest had to be: "...God-conscious and prudent, skilled in Greek writing, and possibly in Slovene-Russian" (Fedotov-Chekhovsky, 1884c: 17). Similarly, the Greeks could deny the priest during the year: "... before the end of the year". The brotherhood decided to keep the priest in accordance with the agreement: "From its general brotherhood assembly..." (Fedotov-Chekhovsky, 1884c: 17). In addition, the blessing led to the spread of the brotherhood in two ways: the involvement of all residents who spoke Greek, and temporarily arrived Greeks in the brotherhood.

Thus, in religious life, the Greek brotherhood was subordinated to Kyiv Metropolitan and Archbishop of Chernihiv until the end of the 17th century, and from the beginning of the 18th century it was subordinated only to the Kyiv metropolitanate.

The attack on the rights of the Greeks by the clergy took place in 1714. The reason for this was the contradictions between the Greek Church and other religious institutions in Nizhyn (Fedotov-Chekhovsky, 1884m: 27-30). In this connection, on October 25 1714, Jozef Krakowski issued an affirmative patent, which ordered the visiting Greeks, as well as the inhabitants of other cities and parishioners of other parishes to apply first to the priests of their parishes when performing church rites. Greek priests also had to pay the archpriest's kvitovy and other taxes. The metropolitan reaffirmed the previous rights of the Greeks on condition of payment of the kvitovy profit to the Kyiv metropolitanate. The brotherhood's annual tax consisted of two wax stones and one incense stone, which had to be delivered to St. Sophia Cathedral (Fedotov-Chekhovsky, 1884m: 27-30).

From time to time, the Greek churches needed repairs and the brotherhood raised money for this purpose. In June 1719, ktetors Mykola and Isaiah asked Bishop Kirill Shumlyansky for permission to repair the Church of St. Michael the Archangel, "which now stands decayed for a long time and requires reparation" (Fedotov-Chekhovsky, 1884a: 27-30). In this connection, on June 18 1719, the Blessed Charter of the administrator of the Kyiv metropolitanate, Bishop Kirill Shumlyansky, was issued, which blessed the restoration of the church. This fact indicates that even such a case as the completion or repair of a church building required the sanction of the Ukrainian church authorities.

On January 11 1728, Kyiv Metropolitan Varlaam Vanatovych issued a decree in which he drew attention to the fact that in the Greek church there was a condition "presbyters live in it for only three years". At the request of the brothers, he allowed the priest Fedor to perform all the proper rites at the Greek church with the hieromonk Melentius, and ordered Father Athanasius to leave the church and move away from the parish, because he had 
remained in his rank for three years (FedotovChekhovsky, 1884n: 39-41).

Both in relations with the Ukrainian hetmans and in relations with Ukrainian spiritual authorities, the Greeks often appealed to the new leadership to confirm their rights. On January 29 1750, Metropolitan Tymofiy Shcherbytsky was attended by representatives of the brotherhood with a report on the rights granted to the Greeks by his predecessors. On the same day, the metropolitan, for his part, reaffirmed all the rights and privileges of the Greeks (Fedotov-Chekhovsky, 1884h: 46-48).

Ten years later, the Greeks needed to prove their rights again. Kyiv Metropolitan Arseniy Mohylyansky, referring to the charter of Varlaam Yasynsky dated September 28 1760, confirmed the rights and privileges of the Greeks and approved Mykola Stefanov, a native of the Greek province Thessaly, as a priest (FedotovChekhovsky, 1884f: 48-54). The brothers also asked the metropolitan to approve their choice and allow Father Mykola to have a priestly service in Greek churches. The Metropolitan granted the request of the Greeks and issued a charter determining the rights and responsibilities of the holy mentor. Subsequently, such charters were given to all appointed priests. The requirements for the members of the clergy were the same: the priest of the Greek churches had the right to take confessions and absolve of sins, baptize, anoint, marry at his discretion. The priest's responsibilities included conscientiously performing all church rites and reporting to the diocese on the activities of the church, as well as providing demographic information.

Thus, the Kyiv metropolitans maintained contact with the brotherhood and coordinated its activities. In July 1772 , the brothers once again asked to confirm the patents granted to them by previous metropolitans. Accordingly, on July 23 1772, Metropolitan of Kyiv and Galicia Gabriel issued a charter confirming all patents granted to the Greeks (Fedotov-Chekhovsky, 1884g: 60-61).

\section{Conclusions}

Summing up, it should be noted that the combination of internal and external critics of charters and universals of Ukrainian highest spiritual authorities, provided to the Nizhyn Greek community, provides an opportunity to draw broad conclusions not only about the features of such informative acts, but also about cultural and religious life of Nizhyn Greeks.

The acts of the highest spiritual authorities demonstrate the great role of Orthodoxy as an ethnoconsolidating factor. Church autonomy was almost a fundamental element of the Greeks' separate legal status in Nizhyn.

The Greek churches in Nizhyn were under the special protection of the Patriarch of Constantinople and were subordinated only to the Kyiv metropolitans. Local church authorities were not allowed to interfere in the spiritual work of the Nizhyn Greeks. The brotherhood gradually developed this independence and it was a necessary condition for its existence. The Ukrainian clergy respected and did not violate the rights granted to the brotherhood at different times.

The Nizhyn Greek Crusade Brotherhood and the churches, school and library at it have long been important centers of Greek culture not only in Ukraine but also in Eastern Europe.

\section{REFERENCES}

Charlampowycz, K. (1924). Narysy z istoriyi greczkoyi koloniyi v Nizhyni (XVII XVIII st.) Zapysky Istoryko-filologichnogo Viddilu UAN. 24: 109-205. (in Ukrainian).

Chernukhin, E. (1998). Greczke nizhynske bratstvo: istoriografiya ta dzherela. Kyiv, 98 p. (in Ukrainian).

Dmitrievsky, A. (1885, February). Grecheskie nezhinskie hramy i ikh vklad v Cerkovno-Arheologicheskij muzej pri Kievskoi Dukhovnoi Akademii. Pravoslavnoe obozrenie. St. Petersburg, Vol .II : 370-400 (in Russian).

Fedotov-Chekhovsky, A. (1884a). Blagoslovennaya gramota administratora Kievskoj mitropolii, episkopa Kirilla Spumlyanskogo. 1719, July, 18. Akty nezhinskogo grecheskogo bratstva. Kyiv. (in Russian).

Fedotov-Chekhovsky, A. (1884b). Blagoslovennaya gramota chernigovskogo arhiepiskopa Lazarya Baranovicha. 1680, March, 11. Akty nezhinskogo grecheskogo bratstva. Kyiv. (in Russian).

Fedotov-Chekhovsky, A. (1884c). Blagoslovennaya gramota kievskogo mitropolita Varlaama Yasinskogo. 1696, July, 3. Akty nezhinskogo grecheskogo bratstva. Kyiv. (in Russian).

Fedotov-Chekhovsky, A. (1884d). Gramota chernigovskogo arhiepiskopa Lazarya Baranovicha. 1680, September, 18. Akty nezhinskogo grecheskogo bratstva. Kyiv. (in Russian).

Fedotov-Chekhovsky, A. (1884f). Gramota Kievskogo mitropolita Arseniya Mogilyanskogo. 1760, September, 28. Akty nezhinskogo grecheskogo bratstva. Kyiv. (in Russian).

Fedotov-Chekhovsky, A. (1884g). Gramota kievskogo mitropolita Gavriila ot 1772, July, 23. Akty nezhinskogo grecheskogo bratstva. Kyiv. (in Russian).

Fedotov-Chekhovsky, A. (1884h). Gramota Kievskogo mitropolita Timofeya Shhebaczkogo. 1750, January, 29. Akty nezhinskogo grecheskogo bratstva. Kyiv. (in Russian).

Fedotov-Chekhovsky, A. (1884j). Gramota patriarha lakova, 1680. Akty nezhinskogo grecheskogo bratstva. Kyiv. (in Russian).

Fedotov-Chekhovsky, A. (1884k). Pismo kievskogo mitropolita Gedeona Svyatopolka. 1686, May, 1. Akty nezhinskogo grecheskogo bratstva. Kyiv. (in Russian).

Fedotov-Chekhovsky, A. (1884I). Oprichnoe pismo arhiepiskopa Lazarya Baranovicha. 1684, May, 10. Akty nezhinskogo grecheskogo bratstva. Kyiv. (in Russian).

Fedotov-Chekhovsky, A. $(1884 \mathrm{~m})$. Utverditelnyj patent Kievskogo mitropolita losafa Krakovskogo ot 25 oktyabrya 1714 g. Akty nezhinskogo grecheskogo bratstva. Kyiv. (in Russian).

Fedotov-Chekhovsky, A. (1884n). Ukaz kievskogo arhiepiskopa Varlaama Vanatovicha. 1728, January, 11. Akty nezhinskogo grecheskogo bratstva. Kyiv. (in Russian).

Fedotov-Chekhovsky, A. (1884p). Blagoslovennaya gramota arhiepiskopa Lazarya Baranovicha. 1683, March, 5. Akty nezhinskogo grecheskogo bratstva. Kyiv. (in Russian).

Fedotov-Chekhovsky, A. (1884r). Akty nezhinskogo grecheskogo bratstva. Kyiv, Kerer, 1884. 84 p. (in Russian).

Hedo, A. (2005). Greczki gromady Nizhyna ta Pivnichnogo Pryazovya $v$ aktovykh materialakh seredyny XVII-XIX st. Kyiv, 416 p. (in Ukrainian).

Morozov, O. (2013). Greczki khramy Nizhyna. Pamyatky Ukrayiny. 2013, 7: 24-31. (in Ukrainian).

Plokhynsky, M. (1905). Inozemcy v Staroj Malorossii. Trudy XII Arheologicheskogo sjezda $v$ Harkove. Moscow: Tipo-Lit., 1905. Vol. 2: 175-409. (in Russian).

Pysma Preosvyashhennago Lazarya Baranovycha (1865, May, 15). Chernigovskie eparhialnye izvestiya. P. 311-317 (in Russian).

Storozhevsky, N. (1963) Nezhinskie greki. Kyiv: Tefo, 1863. 136 p. (in Russian).

Trudy VIII Arheologicheskogo sjezda v Moskve. (1897). Perekaz povidomlenya O. Dmytriyevskogo "Grecheskoe Nezhynskoe bratstvo y ego ustav" Vol. IV. Moscow: Tovaryshhestvo typografyy A.Y. Mamontova, 114-179. (in Ukrainian). 
Анна Гедьо,

Київський університет імені Бориса Грінченка (м. Київ, Україна)

e-mail: a.hedo@kubg.edu.ua, ORCID 0000-0003-4151-0747

Ольга Сараєва,

Приазовський державний технічний університет (м. Маріуполь, Украйна) e-mail: saraeva.ov84@gmail.com,ORCID0000-0001-5305-6751

\section{ХАРТІЇ ТА УНІВЕРСАЛИ УКРАЇНСЬКИХ МИТРОПОЛИТІВ І АРХІЕПИСКОПІВ ДЛЯ НІЖИНСЬКОї ГРЕЦЬКОї ГРОМАДИ: ДЖЕРЕЛОЗНАВЧЕ ДОСЛІДЖЕННЯ}

У статті дається аналіз грамот київських митрополитів, київських і чернігівських архієпископів як актових матеріалів з історії греків Ніжина другої половини XVII - XVIII ст. На основі джерелознавчого та порівняльно-типологічного аналізу розглядається їх еволюція та значення для церковного устрою Ніжинського грецького братства, яке до кінця XVII ст. підпорядковувалося київському митрополиту і чернігівському архієпископу, а з початку XVIII ст. - лише Київській митрополії.

Церковна влада від самого початку поселення греків в м. Ніжині позитивно ставилася до їхніх потреб і надавала їм посильну допомогу. Свідченням цього є численні благословенні грамоти, універсали, накази, „опричні листи” київських митрополитів, київських та чернігівських архієпископів, накази Київської кафедральної консисторії. Більшість 3 них опубліковано в збірці актів О. Федотова-Чеховського, яку було видано 3 архіву Михайлівської церкви в Ніжині. У збірці подано грецькі та слов'янські тексти 24 грамот православних грецьких та українських ієрархів 1680-1784 рр., які надавали грекам право на влаштування власного церковного братства або підтверджували таке право.

Текстологічний та джерелознавчий аналіз публікацій О. Федотова-Чеховського та п'яти універсалів, наданих ніжинським грекам Л. Барановичем, опублікованих невідомими автором у 1865 р. у „Чернігівських єпархіальних відомостях", та матеріалів М. Сторожевського дозволяє виявити суттєві текстові та хронологічні розбіжності.

Ключові слова: джерело; статути; універсали; накази; опричні листи київських митрополитів та чернігівських архієпископів; Ніжинська грецька громада.

(c) Anna Hedo, Olga Sarajeva

Надійшла до редакції: 01.12.2020

Прийнята до друку: 08.04.2021 